\title{
UTILIZATION OF ORGANIC FRACTION OF MUNICIPAL WASTE IN ACCORDANCE WITH THE PRINCIPLES OF CIRCULAR ECONOMY - A CASE STUDY
}

\author{
UDC 338:628.473.6
}

\author{
Gordana Stefanović ${ }^{1}$, Biljana Milutinović ${ }^{2}$ \\ Milica Ivanović ${ }^{1}$, Ana Momčilović ${ }^{1}$ \\ ${ }^{1}$ University of Niš, Faculty of Mechanical Engineering, Serbia \\ ${ }^{2}$ College of Applied Technical Sciences Niš, Niš, Serbia
}

\begin{abstract}
The organic fraction of municipal waste $(M W)$ is a huge resource of nutrients and energy, primarily because of the high content of carbon as well as potassium and phosphorus. On the other hand, having in mind the problems that cities are faced with, such as energy supply, transportation, environmental pollution and many others, waste management has to be considered as an integral part of city management. Circular economy is a new concept of thinking which implies that all streams of a system should be considered as a possible resource, including waste. The organic part of municipal waste can be used in several ways. Anaerobic digestion (AD) that produces biogas and compost can be a part of the chain of circular economy of a city. This paper deals with the organic waste generated on the territory of the city of Nis with the focus on its potential in terms of carbon, hydrogen and mineral content. Based on the elementary analysis and quantity of waste, the streams of carbon and other elements that circulate through waste, biogas and compost have also been analyzed. Moreover, energy needs for $A D$ function and transportation of both $M W$ and compost are calculated. The analysis shows that the energy produced by AD can cover the energy needs for the proposed model, and the amount of produced compost is enough to recover nutrients on the majority of green yards in the city.
\end{abstract}

Key words: Circular economy, energy, organic waste, compost.

\section{INTRODUCTION}

The first steps in the evaluation of MW began with the fractions that were easiest to select from the waste mixture, and which could be quickly recovered and given back to the market (metal, glass, plastic).

Received March 27, 2017 / Accepted June 1, 2017

Corresponding author: Gordana Stefanović

University of Niš, Faculty of Mechanical Engineering, Aleksandra Medvedeva 14, 18000 Niš, Serbia

E-mail: gordana.stefanovic@masfak.ni.ac.rs 
Organic waste (OW) as a part of municipal waste has been neglected for a long time although it contains many valuable raw materials which can be extracted with the appropriate techniques.

The quantity of OW in MW varies and depends of many factors. As a country gets urbanized and its population becomes richer, consumption of inorganic materials (such as plastics, paper, and metal) increases, while the relative organic fraction decreases. Generally, low and middle-income countries have a high percentage of organic matter in the urban waste stream, ranging from 40 to $85 \%$ of the total. The average global content of organic matter in the urban waste stream for 2005 was $46 \%$ [1]. Such a high content of organic matter even in the richest countries is a challenge in terms of finding a way for its maximal usage.

Organic municipal waste is a total sum of organic waste that is produced in households (food waste), green yards (grass clippings, leaves and bushes), green markets, etc. The waste content is different and varies depending on the type and origin. To illustrate the potential of household waste, different elementary and chemical analyses have been made. The study conducted by Pleisner et al. showed that in dry OW there was $45-75 \%$ carbohydrates (including 30-60\% starch), 5-10\% proteins, $7-40 \%$ lipids, and 10$15 \%$ minerals (including phosphorus and potassium) [2]. There is evident depletion of phosphorus in soil on the whole planet. The studies in Sweden and Hong Kong showed that the content of phosphorus in organic waste was cca. $1.9 \mathrm{mg} / \mathrm{g}$ of dry matter. Simplified calculation on an annual level gives the quantity of $\mathrm{P}$ in the landfill of a city with 300.000 inhabitants of about 125 t P [3]. Sugars, amino acids, fatty acids, P from inorganic part can be used in biotechnological processes [4]. Karmee and Lin [5] showed that the remaining solid fraction after hydrolysis, rich in lipids, can be used as a source for fatty acids in chemical reactions.

Utilization of organic waste has several important objectives. Firstly, by treating OW the negative impact to the environment is reduced. Then, through the fermentation process of $\mathrm{OW}$ and production of biogas, OW is considered as a renewable energy source. Finally, there is a possibility of nutrients recycling and their return to the nature.

Nowadays there are several techniques for organic waste treatment. Biological methods (anaerobic digestion and composting) are distinguished as more appropriate in a sustainable way, where AD has found more application because of better utilization of matter. From $1 \mathrm{t}$ of $\mathrm{OW}$ it is possible to obtain about $400 \mathrm{~kg}$ of compost by the composting process, but through $\mathrm{AD}$ biogas is also produced (from $1 \mathrm{t}$ of $\mathrm{OW}$ it is possible to obtain $400-600 \mathrm{~m}^{3}$ of biogas) [6].

Regardless of the treatment considered, the modern concept of sustainable development suggests that waste has to be realised as a resource, where all the above presented aims will be achieved through circular economy (CE). The principles of CE, as opposed to the linear economy with the product life "from cradle to grave", considers the broader picture and includes all parts of the life cycle of the products, "from cradle to cradle" $[7,8,9]$. There are many examples of inclusion of waste streams in circular economy of the cities and regions. A research in China showed that in densely populated areas significant ecological and economic effects can be achieved when CE is applied [3]. An interesting example is a Danish town where the system is brought to the final goal "food -waste-food" [10].

The aim of this paper is to show that the organic waste generated in the households and on the green yards of the city of Nis, can be utilized as a source of energy and 
nutrients by applying the principles of CE. Organic waste is converted into biogas and compost through anaerobic digestion, where the compost with nutrients is returned to the green areas. Biogas is used as fuel to cover the needs of the proposed model: maintenance of digester function, transportation of $\mathrm{OW}$ from the place of generation to the AD plant, as well as for transportation of compost from the plant to the green areas.

\section{MODEL DESCRIPTION}

Based on the quantity and composition of OW, we made a model for waste management in the city is made where the organic waste is observed as a raw material for energy and compost production. The model predicts the collection of OW from households and public and private green yards. The produced compost is returned to green areas to meet the needs for nutrients, while biogas is used to cover the energy needs for the whole process (see Fig.1). The aims of the proposed model are to decrease environmental pollution, to increase the usage of renewable resources, while achieving $\mathrm{CO}_{2}$ reduction and nutrients recovering, which leads to the improvement of the local economy.

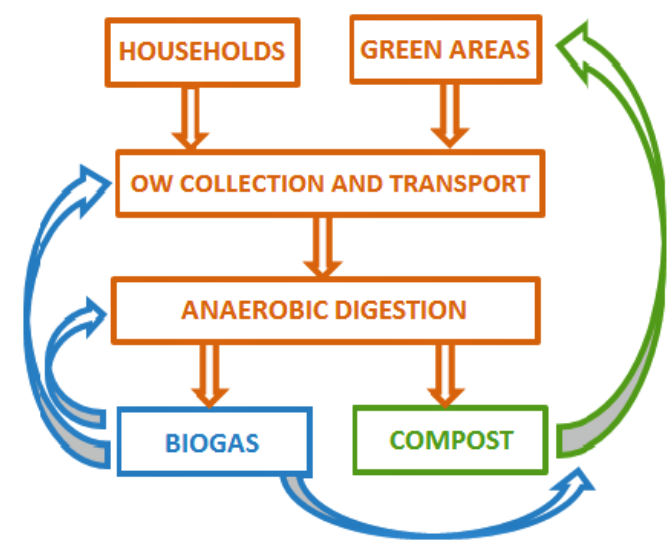

Fig. 1 Model for organic waste management

Processing of organic waste is conducted in a continuous anaerobic digester. The process is thermophilic. To enable the hydrolysis process in a digester it is necessary to provide the required conditions of temperature, $\mathrm{pH}$ and purity of raw materials. Therefore, it is necessary to ensure that during the process of collection of $\mathrm{OW}$ from households and green areas there is no contamination of OW with hazardous waste and metal. Hazardous substances can cause the destruction of a colony of bacteria [11], and the presence of metal inhibits the process of hydrolysis [12], which leads to an inefficient process and ultimately to its stopping. Maintaining the temperature in the digester is provided by the energy obtained from biogas.

The model predicts that OW is collected daily. Vehicles use biogas produced in the digester as fuel. Calculation of material and energy flows is made on the basis of the literature data and experimental results. 


\section{EXPERIMENTAL RESEARCH}

\subsection{Study area}

For the purpose of this research, the city of Niš, an industrial and university center, situated in the southeast of the Republic of Serbia, was observed as a case study. The resource considered was organic waste generated by 80,000 households and collected from the green areas of the city. The yearly amount from households is 9,011.50 t wet food waste, i.e. 2,703.4 t dry waste (moisture content is $70 \%$ ). The amount of wet yard waste is $8,854.50 \mathrm{t}$, i.e. $3,542.0 \mathrm{t}$ dry waste (Table 1). The total amount of wet and dry waste is $17,866 \mathrm{t}$ and $6,245.4 \mathrm{t}$, respectively.

Table 1 The amount of municipal organic waste in the City of Niš

\begin{tabular}{lccc}
\hline Waste fractions & $\begin{array}{c}\text { Quantity, wet } \\
(\mathrm{t} / \text { year) }\end{array}$ & $\begin{array}{c}\text { Moisture } \\
(\%)\end{array}$ & $\begin{array}{c}\text { Quantity, dry } \\
(\mathrm{t} / \text { year })\end{array}$ \\
\hline Food waste & $9,011.50$ & 70.0 & $2,703.4$ \\
Yard waste & $8,854.50$ & 60.0 & $3,542.0$ \\
Sum & $17,866.00$ & 67.0 & $6,245.4$ \\
\hline
\end{tabular}

The average elementary composition of organic waste as food waste and yard waste is presented in Table 2 [13]. Evangelisti et al. [14] have showed that for a stable anaerobic digestion the ratio between $\mathrm{C}$ and $\mathrm{N}$ should be in the range from 20 to 30 . Under these conditions the specific biogas yield is $400 \mathrm{~m}^{3}$ per ton [15]. From the content of $\mathrm{C}$ and $\mathrm{N}$ (Table 2) the calculated $\mathrm{C} / \mathrm{N}$ ratio for food waste is 18.4 , and for yard waste 13.3 , which shows that for food waste the ratio is slightly below the optimum, while for yard waste it is even more below. It is necessary to consider the co-digestion as one of the options and include the specific type of organic waste with a higher content of $\mathrm{C}$ in the waste streams.

Based on the literature and data from the field, one can estimate the amount of certain nutrients contained in waste. The total amount of carbon, hydrogen, nitrogen, oxygen, sulfur, mineral substances is presented in Table 2.

Table 2 The composition of total organic waste

\begin{tabular}{lrrrr}
\hline Composition & Food waste & Yard waste & \multicolumn{2}{c}{ Total } \\
\cline { 2 - 5 } & \multicolumn{1}{c}{$\%$} & \multicolumn{1}{c}{$\%$} & \multicolumn{1}{c}{ t } \\
\hline Cs & 48.0 & 47.8 & 47.9 & 3000 \\
Hs & 6.4 & 6.0 & 6.2 & 388 \\
Os & 37.6 & 37.7 & 37.6 & 2352 \\
Ns & 2.6 & 3.6 & 3,1 & 194 \\
Ss & 0.4 & 0.33 & 0.35 & 22 \\
Minerals & 5.0 & 4,5 & 4.75 & 297 \\
C/N & 18.4 & 13.3 & & \\
\hline
\end{tabular}

\subsection{Production of compost and biogas}

The quantity of digestate and biogas created in the process of anaerobic digestion can be calculated based on the elementary composition and amount of dry waste. First of all, the composition of biogas is calculated by using Buswell Equation [16]: 
$\mathrm{C}_{c} \mathrm{H}_{h} \mathrm{O}_{o} \mathrm{~N}_{n} \mathrm{~S}_{s}+\frac{1}{4}(4 c-h-2 o+3 n+2 s) \mathrm{H}_{2} \rightarrow \frac{1}{8}(4 c-h+2 o+3 n+2 s) \mathrm{CO}_{2}+$ $\frac{1}{8}(4 c+h-2 o-3 n-2 s) \mathrm{CH}_{4}+n \mathrm{NH}_{3}+s \mathrm{H}_{2} \mathrm{~S}$

Where $\mathrm{c}, \mathrm{h}, \mathrm{o}, \mathrm{n}$, and $\mathrm{s}$ are the numbers of molls of carbon, hydrogen, oxygen, nitrogen, sulfur, minerals in OW, respectively.

According to the elementary analysis of food waste and yard waste presented in Table 2 the composition of biogas is obtained: $57 \% \mathrm{CH}_{4}, 42 \% \mathrm{CO}_{2}, 1 \% \mathrm{NH}_{3}$ and $\mathrm{H}_{2} \mathrm{~S}$. Energy yield from biogas is calculated taken into account that the low heating value of methane is $36 \mathrm{MJ} / \mathrm{m}^{3}$.

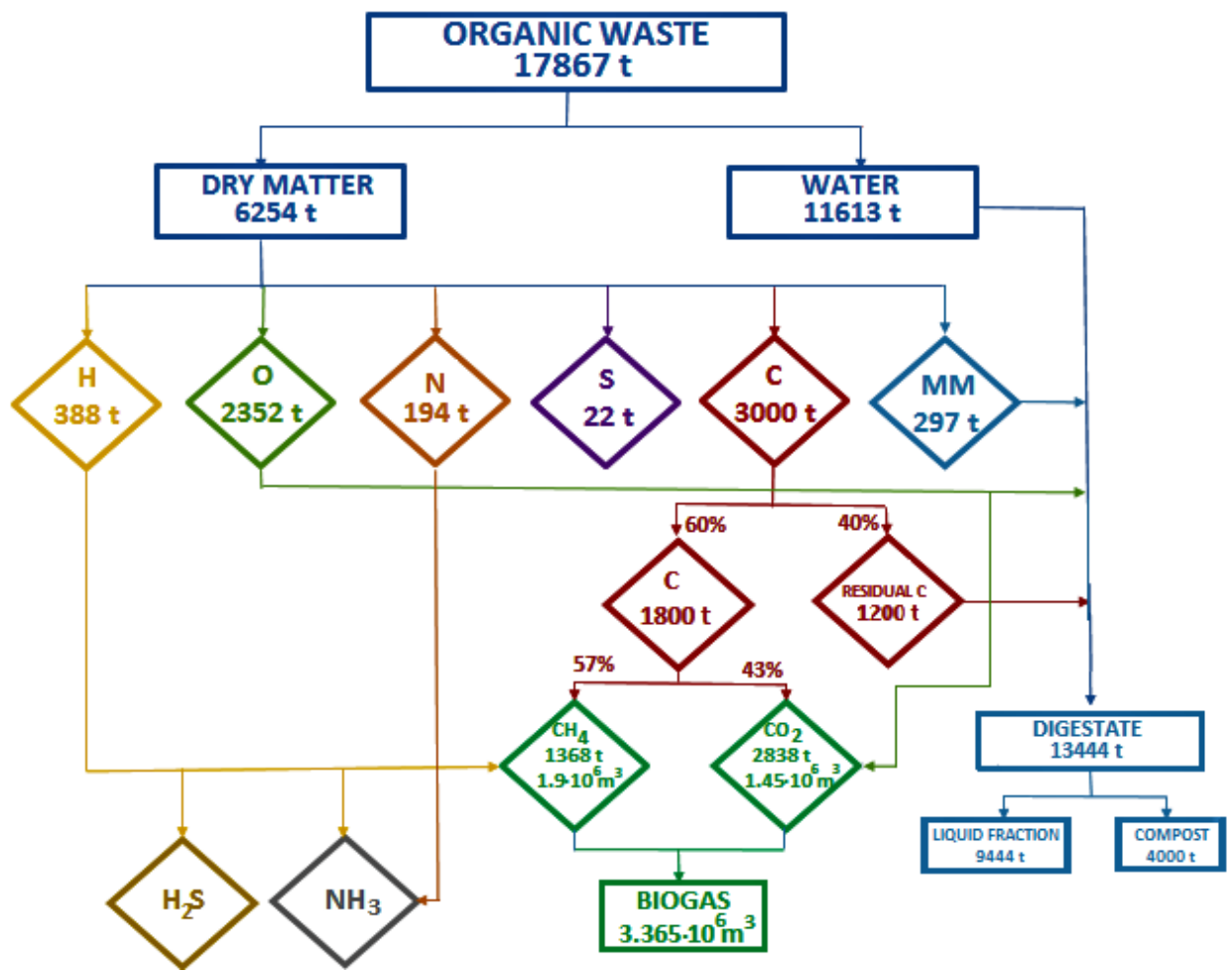

Fig. 2 Material flow of OW treatment

In the following section, based on the elementary composition and quantity of waste the amount of all the elements in the waste is calculated and displayed (Table 2). The obtained values are used to calculate the material flows of all elements included in the anaerobic digestion. It is assumed that the percentage of biodegradable carbon is $60 \%$, which is partly used for the production of $\mathrm{CO}_{2}$ according to the presence of $\mathrm{O}$ in the waste and the other part to produce $\mathrm{CH}_{4}$ based on the amount of $\mathrm{H}$. The rest of $\mathrm{H}$ is used to produce $\mathrm{H}_{2} \mathrm{~S}$ and $\mathrm{NH}_{3}$. The amount of residual organic solid (40\% non-biodegradable C) is $1200 \mathrm{t}$ per year. In the schematic presented in Figure 2 the material flow of the overall $\mathrm{OW}$ is presented. 
The amount of digester produced per year is calculated based on the water content in the wet $\mathrm{OW}$, residual $\mathrm{C}$ and minerals and it is 13,444 t. After processing, 4000 tons of compost can be obtained.

The quantity of produced biogas is 3,365 million $\mathrm{m}^{3} / \mathrm{year}$ from what 1,915 million $\mathrm{m}^{3} /$ year is $\mathrm{CH}_{4}$ and 1,45 million $\mathrm{m}^{3} /$ year is $\mathrm{CO}_{2}$. These values are theoretical.

\subsection{The needs for compost}

The public green areas on the territory of Niš are mainly parks with a surface of $3,030,526 \mathrm{~m}^{2}$. According to Wynd et al. [17], for $1 \mathrm{~m}^{2}$ of land, $1.23 \mathrm{~kg}$ of fertilizers is needed annually. On yearly basis, for public green areas in the city of Niš the amount of $3,728 \mathrm{t}$ of compost is needed.

\subsection{Energy needs for the whole system}

According to the provided model, the energy obtained from biogas is used to meet the energy needs to run the AD process and facility, transport OW to the biogas facility, and transport compost to green areas (Fig. 1).

\subsubsection{Digester maintenance}

The required energy for the AD process is used to heat the substrate at the entrance of the digester, to maintain the temperature in the $\mathrm{AD}$ at $60{ }^{\circ} \mathrm{C}$, and to cover the heat loss from the digester walls. The heat loss through the walls of digester is small and can be ignored.

For the purposes of calculating the energy balance of the process in the digester the following assumptions were adopted: specific heat capacity of the waste is equal to the specific heat capacity of water $\mathrm{c}=4,186 \mathrm{~J} / \mathrm{kg} \mathrm{K}$; the substrate temperature at the entrance of the digester is equal to the average external temperature of air in the city of Niš from $13{ }^{\circ} \mathrm{C}$ and the coefficient of heat transfer through the walls of the digester exposed to the outdoor air is $\mathrm{k}=0.70 \mathrm{~W} / \mathrm{m}^{2}{ }^{\circ} \mathrm{C}$.

The amount of energy needs for the heating of digester is 50,223,662 MJ / year, while for the substrate heating it is 3,437,752 MJ / year (Table 3).

\subsubsection{OW transportation}

The energy required for the transportation of OW from the point of generation to the $\mathrm{AD}$ facilities is calculated based on the distance same as the routes by which solid waste is currently transported from the place of generation to the city landfill. The biogas plant is located near the landfill. For the transport of $1 \mathrm{t}$ of waste from the places of generation to the biogas plant, 7.141 of diesel fuel is required, that is $9.78 \mathrm{~m}^{3}$ of biogas $\left(1.37 \mathrm{~m}^{3}\right.$ of biogas can replace 11 of diesel fuel, according to the relation of lower heating value of diesel fuel and biogas). Consumption of diesel for MSW transportation is 466,949 1/year, e.g. for OW it is $127,6631 /$ year. The annual consamption of biogas for OCW would be 4,978,829 MJ (Table 3). 


\subsubsection{Compost transportation}

Calculation of the biogas amount needed for compost transportation from the AD plant to green yards is made by adopting the same assumption like that which was used for OW transportation. Based on that, the energy required for transportation of $4000 \mathrm{t}$ of compost, $69,167.5 \mathrm{~m}^{3}$ of biogas, i.e. 1,798,355 MJ is estimated (Table 3).

\section{RESULTS}

Based on the composition and the quantity of organic waste generated in the city of Niš, the theoretical amount of biogas and compost is calculated. Also, the amount of energy needed to sustain the anaerobic digester is assumed. Bearing in mind that organic waste should be seen as an energy and material resource, the possibility of using the potential of organic waste, not only to cover the need for the maintenance of AD but also to meet the needs of the city for energy and nutrients, has been discussed.

Table 3 Energy flow of the proposed model

\begin{tabular}{llrrrr}
\hline Energy & \multicolumn{2}{c}{ Annual } & \multicolumn{2}{c}{ Per day } \\
\cline { 2 - 6 } & \multicolumn{1}{c}{ MJ } & \multicolumn{1}{c}{$\mathrm{m}^{3}$} & \multicolumn{1}{c}{ MJ } \\
\hline Energy obtained from biogas & $78,867,500$ & $3,365,000$ & 216,000 & 10,137 \\
& Digester heating & $50,223,662$ & $1,931,679$ & 137,764 & 5,299 \\
Energy & Substrate heating & $3,437,752$ & 132,221 & 9,418 & 362 \\
requirements & OW transport & $4,978,829$ & 191,493 & 13,645 & 525 \\
& Compost transport & $1,798,355$ & $69,167.5$ & 4,927 & 190 \\
\hline Energy surplus & $\mathbf{1 8 , 4 2 8 , 9 0 2}$ & $\mathbf{1 , 0 4 0 , 4 3 9 , 5}$ & $\mathbf{6 3 , 8 9 1}$ & $\mathbf{3 , 7 6 1}$ \\
\hline
\end{tabular}

From Table 3 it can be seen that the quantity of energy obtained from biogas annually is $78,867,500 \mathrm{MJ}$, while the energy required for $\mathrm{AD}$ process as well as for transport of OW and compost is $60,438,598 \mathrm{MJ}$. It can be noted that the theoretically produced energy from $\mathrm{OW}$ can meet the energy needs for the proposed model.

Regarding nutrients recovering through $\mathrm{AD}$ compost production, it can be concluded that the amount of generated compost of $4000 \mathrm{t}$ is a bit higher than the minimum needed quantity of compost for the public green areas $(3,728 \mathrm{t})$.

\section{CONCLUSION}

By applying the principles of circular economy on the OWM in the city different benefits can be achieved. When OW is observed as a resource with its energy and nutrient potential, it could lead to the reduction of pollution, an increased level of recycling by nutrients recovery, saving virgin raw materials, increased renewable energy consumption by using biogas as a fuel, and improvement of local economy through all these activities.

The paper describes the use of OW and its conversion into biogas and compost, and their contribution to the circular economy of one city. Biogas would be used as an energy resource, and compost would be sent to the green areas for nutrients recovery. 
Based on the elementary analysis and the amount of available OW, the quantities of produced biogas and compost are calculated. The amount of obtained biogas of 3,365,000 $\mathrm{m}^{3}$ can cover the energy needs for operating the proposed model. Also, the quantity of compost produced (i.e. 4,000 t) can meet the need for nutrients in green areas of the city.

Having in mind the above facts, it can be concluded that the treatment of organic waste by the process of anaerobic digestion is sustainable in terms of energy and material reuse, and can, therefore, be seen as a part of circular economy of the city.

\section{REFERENCES}

1. Waste Composition - World bank, 2005 - Available at: <http://siteresources.worldbank.org/INTURBANDEVELOPMENT/Resources/3363871334852610766/Chap5.pdf > [accessed 20.12.2016].

2. Pleissner, D., Kwan, T.H., Lin, C.S.K., Fungal hydrolysis in submerged fermentation for food waste treatment and fermentation feedstock preparation, Bioresource Technology, Vol.158, pp. 48-54,2014.

3. Pleisner D., Decentralized utilization of wasted organic material in urban areas: A case study in Hong Kong, Ecology Engineering, Vol.86, pp. 120-125, 2016.

4. Agudelo-Vera, C.M., Mels, A., Keesman, K., Rijnaarts, H., The urban harvest approach as an aid for sustainable urban resource planning, Journal of Industrial Ecology, Vol.16, pp. 839-850, 2012.

5. Karmee, S.K., Lin, C.S.K., Lipids from food waste as feedstock for biodiesel production: case Hong Kong, Lipid Technology Vol.26, pp.206-209, 2014

6. Murphy, J. \& Power, N.,. A Technical, Economic and Environmental Comparison of Composting and Anaerobic Digestion of Biodegradable Municipal Waste. Journal of Environmental Science and Health, Part A, Vol. 41, pp. 865-879, 2006.

7. Preston F., A global Redesign? Shaping the Circular Economy, London: Chatham House; 2012.

8. Su B., Heshmati A., Geng Y., Yu X., A review of the circular economy in China: moving from rhetoric to implementation. J Cleaner Product, Vol.42, pp.215-227, 2013

9. Fujita G. Y., Chen X.D., Evaluation of innovative municipal solid waste management through urban symbiosis: a case study of Kawasaki, J Cleaner Product, Vol.18, pp.993-1000, 2010.

10. Stoknes K., Scholwin F., Krzesinski W., Wojciechowska E., Jasinska A., Efficiency of a novel "Food to waste to food" system including anaerobic digestion of food waste and cultivation of vegetables on digestate in a bubble-insulated greenhouse, Waste Management, Vol.56, pp. 466-476, 2016.

11. Mata-Alvarez, J., 2003. Biomethanization of the organic fraction of municipal solid wastes. London: IWA Publishing.

12. City of Niš. Official web site - Avaliable at: <http://www.ni.rs> [accessed 12.12.2016].

13. Tchobanogloous, G., Theisen, H. \& Vigil, S., 1993. Integrated Solid Waste Management, Engineering Principles and Management Issues. McGraw-Hill, Inc.

14. Evangelisti, S., Lettieri, P., Borello, D., Clift, R., Life cycle assessment of energy from waste via anaerobic digestion: a UK case study, Waste Management, Vol.34, pp. 226-237, 2014.

15. Borowski, S., Domanski, J., Weatherley, L., Anaerobic co-digestion of swine and poultry manure with municipal sewage sludge, Waste Management, Vol.34, pp.513-521, 2014.

16. Buswell, A. M. \& Mueller, H. F., Mechanisms of Methane Fermentation. Industrial \& Engineering Chemistry, Vol.44, p.p. 550-552, 1952.

17. Wynd, F. L. Feed the Soil, Scientific Monthly, Vol.74, pp. 223-229, 1952. 


\section{PRIMENA PRINCIPA CIRKULARNE EKONOMIJE NA ISKORIŠĆENJE ORGANSKOG DELA KOMUNALNOG OTPADA}

Organski otpad $(O O)$ koji se nalazi u komunalnom otpadu je ogroman resurs nutrijenata $i$ energije, pre svega zbog visokog sadržaja ugljenika, ali i zbog kalijuma i fosfora. Na drugoj strani, imajući u vidu probleme sa kojima se suočavaju moderni gradovi kao što je snabdevanje energentima, transport, zagađenje životne sredine i mnogi drugi upravljanje otpadom mora da se posmatra kao deo integralnog sistema upravljanja gradom. Cirkularna ekonomija je novi koncept razmišljanja koja nas primorava da sve tokove jednog sistema posmatramo kao mogući resurs, uključujući i otpad. Iskorišćenje organskog dela komunalnog otpada može biti izvedena na višse načina. Aanaerobna digestija (AD) sa proizvodnjom biogasa i komposta može biti karika u lancu cirkularne ekonomije jednog grada.

U ovom radu je razmatran organski otpad koji nastaje na teritoriji grada Niša i njegovi potencijali koji se ogledaju sadržaju ugljenika, vodonika i minerala. Na osnovu elementarne analize $i$ količina otpada napravljena je analiza tokova elemenata koji učestvuju u nastajanju biogasa i komposta. Takođe, izvršena je analiza energetskih potreba za rad anaerobnog digestora kao i za transport OO i komposta. Analiza je pokazala da energija koja se dobija anaerobnom digestijom može da pokrije sve energetske potrebe celog ciklusa, a dobijena količina komposta je dovoljna za zadovoljeenje potreba zelenih gradskih površina za nutrijentima.

Ključne reči: cirkularna ekonomija, energija, organski otpad, kompost. 